\title{
Efficacy of some insecticides against Thrips, Megalurothrips sjostedti Trybom cowpea crop ecosystem
}

\author{
Gopi Ram Yadav', Poonam Srivastava', Vijay Kumar Mishra ${ }^{2 *}$, Deepika Chauhan and \\ Rajveer $^{1}$ \\ ${ }^{1}$ Department of Entomology, G. B. Pant University of Agriculture and Technology, Pantnagar-263145 (Uttarakhand), \\ INDIA \\ ${ }^{2}$ Department of Entomology and Agricultural Zoology, Institute of Agricultural Sciences, Banaras Hindu \\ University, Varanasi-221005 (Uttar Pradesh), INDIA \\ *Corresponding author. E-mail: premvijaybhu@gmail.com
}

Received: May 31, 2016; Revised received: October 26, 2016; Accepted: February 9, 2017

\begin{abstract}
The study was conducted to determine efficacy of insecticides against Thrips, Megalurothrips sjostedti Trybom on cowpea grown at field experiments were conducted at Breeder Seed Production Centre, Govind Ballabh Pant University of Agriculture and Technology, Pantnagar 2014. The most effective treatment for the control of thrips Megalurothrips sjostedti Trybom was seed treatment with fipronil @ $3 \mathrm{ml} / \mathrm{kg}+$ spray with fipronil @ $5 \mathrm{ml} / \mathrm{lt}$ with maximum reduction $(70.06 \%)$ in the thrips population of cowpea while lowest effective treatment for the control of thrips Megalurothrips sjostedti Trybom was seed treatment with imidacloprid $17.8 \mathrm{SL} @ 10 \mathrm{ml} / \mathrm{kg}+$ spray with monocrotophos 36SL @ 2ml/lt with minimum reduction (16.02\%) in the thrips, Megalurothrips sjostedti Trybom population of cowpea crop.
\end{abstract}

Keywords: Cowpea crop, Efficacy, Fipronil 20 SC , Imidacloprid 17.8 SL, Monocrotophos 36SL, Megalurothrips sjostedti Trybom (Thrips)

\section{INTRODUCTION}

Cowpea (Vigna unguiculata L.) is one of the important leguminous crops also known as crowder pea, black-eyed bean or Southern pea in English, while Chola or Choli, Chavli, Lobia in various vernacular languages in India with highly nutritive values. The cowpea is originated from Africa and widely grown in Africa, Latin America, Southeast Asia and in the Southern United States. Cowpea is cultivated in the tropical and subtropical regions. Worldwide cowpea is cultivated in approximately 11.36 million hectare area, production is 5.19 million tonnes, and yield is $460 \mathrm{~kg} / \mathrm{ha}$ (Akibode and Maredia , 2011). Area under cowpea in India is 3.9 million hectare with a production of 2.21 million tonnes with the national productivity of $683 \mathrm{~kg} / \mathrm{ha}$. Thrips (Thysanoptera, Thripidae) are small, opportunistic and ubiquitous insects of often only a few millimeters length and generally yellow, brown or black in color (Morse and Hoddle, 2006). Thrips frequently inhabit flowers or inflorescence of various kinds, shoots, tender leaves, and fungus-infested dead or decaying wood. Most thrips complete their life cycle from egg to adult stage in two to three weeks. The duration varies with the host and with abiotic factors such as temperature and humidity (Andrewartha, 1971). Singh and Allen (1980) reported that damage caused by foliar thrips feeding at the seedling stage resulted in yield losses up to $15 \%$ in West Africa. during the pre-flowering period, M. sjostedti nymphs and adults may damage the terminal leaf buds and bracts/stipules, causing the latter to become deformed with a brownish yellow mottled appearance (Ezueh, 1981). However, the principal point of plant attack is on the flower buds and later, on the flowers themselves (Singh and Taylor, 1978). Attacked flower buds become brown and eventually abort (Singh, 1977), leaving behind dark red scars (Akingbohungbe, 1982). Flower damage is characterized by a distortion, malformation, and discoloration of floral parts (Singh and Taylor, 1978). Flower thrips populations are higher during the dry season, which favors rapid multiplication of thrips (Agyen-Sampong, 1978; Ezueh, 1981). When the thrips population is very high, open flowers are distorted and discolored. Flowers fall early with the result that pods are not formed and causing yield losses between 20 and $70 \%$ depending on the severity of infestation (Tamo et al., 1993). The indiscriminate use of insecticides by the farmers to control the various pests have resulted hazardous effects to the environment. Unforeseen side effects such as toxicity to non-target organisms, development of resistance in pests to the pesticides and environmental contamination greatly 
affect the entire food chain. Sucking pests have developed resistance to almost all conventional synthetic insecticides and also developing resistance to multiple classes of insecticides (Palumbo et al., 2001, Kady and Devine, 2003). Moreover, conventional insecticides provide poor control of insect pests and generally lead to pest resurgence. Therefore, to overcome these problems the use of new generation chemical neonicotinoids is the ultimate alternative for effective pest management. Considering the importance of the insect pests of cowpea, the experiments have been planned to find out the field efficacy of different pesticides namely biopesticides (neem), microbial pesticide (spinosad) and chemical pesticides (quinalphos, profenofos, lambda-cyhalothrin, thiamethoxan and imidacloprid) against major field Thrips of cowpea. The focus has also been made on the development of newer chemistries-newer classes of products with novel mode of action that are active at very low dosages and manage Thrips population.

\section{MATERIALS AND METHODS}

The field experiments were conducted at Breeder Seed Production Centre, Govind Ballabh Pant University of Agriculture and Technology, Pantnagar. Twenty four plots of varieties Pant lobia-3 were demarcated and arranged in randomized block design with three replication of eight treatments. Each plot had five rows. The plot size was $4 \times 2.25 \mathrm{~m}^{2}$ with $45 \mathrm{~cm}$ row spacing. The test crop was cowpea varieties Pant Lobia-3. Sowing of cowpea variety Pant Lobia-3 was done on $20^{\text {th }}$ March 2014 during Zaid .

Methodology: For seed treatment, desired quantities of insecticides as per concentrations were thoroughly mixed with seeds. After treating, the seeds were kept for overnight drying in shade at room temperature, before sowing. Hundred grams of seeds were taken in each case of sowing in an area of $4 \times 2.25 \mathrm{~m}^{2}$. The crop received two sprays; during the Zaid seasons, first spray was given at 30 days after sowing on $14^{\text {th }}$ of May 2014 , the second spray was given sequentially with an interval of 15 days on $25^{\text {th }}$ of May. All the treatments were imposed by using high volume knapsack sprayer @ 500 liters of spray solution per hectar. The experiments were carried out with eight treatments of various insecticides in randomized block design with three replications. The treatment details are given in above table. Estimation of population density of thrips was done by randomly selected ten flower buds per ten plants per plot from vegetative to harvesting crop stage. Similarly. The pretreatment observation of Thrips population, were taken one day before, while post treatments at 3,7,10 and 14 day after each spray. Statistical analysis: The obtained data from various experiments were subjected to analysis of variance (ANOVA) using Randomized Block Design (RBD). Significant means were compared using Duncan's
Multiple Range Test (DMRT) at 5\% probability test.

\section{RESULTS AND DISCUSSION}

Efficacy of various insecticides against thrips, Megalurothrips sjostedti Trybom. in cowpea during Zaid season of the year 2014: In present investigation, efficacy of total seven insecticides were evaluated against Megalurothrips sjostedti Trybom The result showed that there was significantly higher thrips population on the cowpea flowers before insecticide application. The insecticidal treatments drastically reduce $(p>0.05)$ thrips population compared with the untreated control.

The efficacy of imidacloprid at 17.8SL @ 5ml/lt (T1), monocrotophos 36SL@2ml/lt (T2), seed treatment with imidacloprid $17.8 \mathrm{SL} @ 5 \mathrm{ml} / \mathrm{kg}+$ spray with imidacloprid 17.8SL@5ml/lt (T3), seed treatment with imidacloprid $17.8 \mathrm{SL} @ 5 \mathrm{ml} / \mathrm{kg}+$ spray with monocrotophos 36SL@2ml/lt (T4), seed treatment with imidacloprid 17.8SL @ 10ml/kg + spray with imidacloprid 17.8SL@ @ $\mathrm{ml} / \mathrm{lt}$ (T5), seed treatment with imidacloprid $17.8 \mathrm{SL} @ 10 \mathrm{ml} / \mathrm{kg}$ + spray with monocrotophos 36SL@2ml/lt (T6), seed treatment with fipronil @ $3 \mathrm{ml} / \mathrm{kg}+$ spray with fipronil @ $5 \mathrm{ml} / \mathrm{lt}$ (T7) and untreated control (T8) were evaluated against thrips and the average number of thrips/flower bud/ plant and \% reduction in thrips population over control have been summarized in tables. All the treatments were applied two times; the first application was done at 30 days after sowing on $14^{\text {th }}$ of May 2014, the second spray was given sequentially with an interval of 15 days on $25^{\text {th }}$ of May.

Efficacy against thrips, Megalurothrips sjostedti Trybom: Results presented in the Tables 1 and 2 revealed that after 3 days of $1^{\text {st }}$ application the highest $\%$ reduction $(70.06 \%)$ in thrips population was recorded in the plot treated with treatment seed treatment with fipronil @ $3 \mathrm{ml} / \mathrm{kg}+$ spray with fipronil @ $5 \mathrm{ml} / \mathrm{lt}$ (T7) with lowest thrips population 2.26 thrips/flower bud/plant. However, treatments seed treatment with imidacloprid 17.8SL @ 5ml/kg + spray with imidacloprid 17.8SL @ 5ml/lt (T3) and seed treatment with imidacloprid 17.8SL @ $10 \mathrm{ml} / \mathrm{kg}+$ spray with imidacloprid 17.8SL @ 5ml/lt (T5) recorded $54.12 \%$ and $53.80 \%$ reduction in thrips population (3.46 and 3.33 thrips/flower bud/plant, respectively) and found statistically at par with each other. Whereas, significantly lowest \% reduction in thrips population was recorded in the treatment monocrotophos 36SL @ 2ml/lt(T2) with 28.04\% (5.60 thrips/flower bud/plant). The $\%$ reduction in thrips population was significantly higher $(\mathrm{p}<0.05)$ in the treatment $\mathrm{T} 7, \mathrm{~T} 5$ and $\mathrm{T} 3$ as compared to $\mathrm{T} 1, \mathrm{~T} 4$ and T6.

The observation at 7 days indicated that the number of thrips was slightly increased in all treatments. Although, significantly highest reduction in thrips population was observed in the treatments fipronil @ 3 
Gopi Ram Yadav et al. / J. Appl. \& Nat. Sci. 9 (1): 415- 420 (2017)

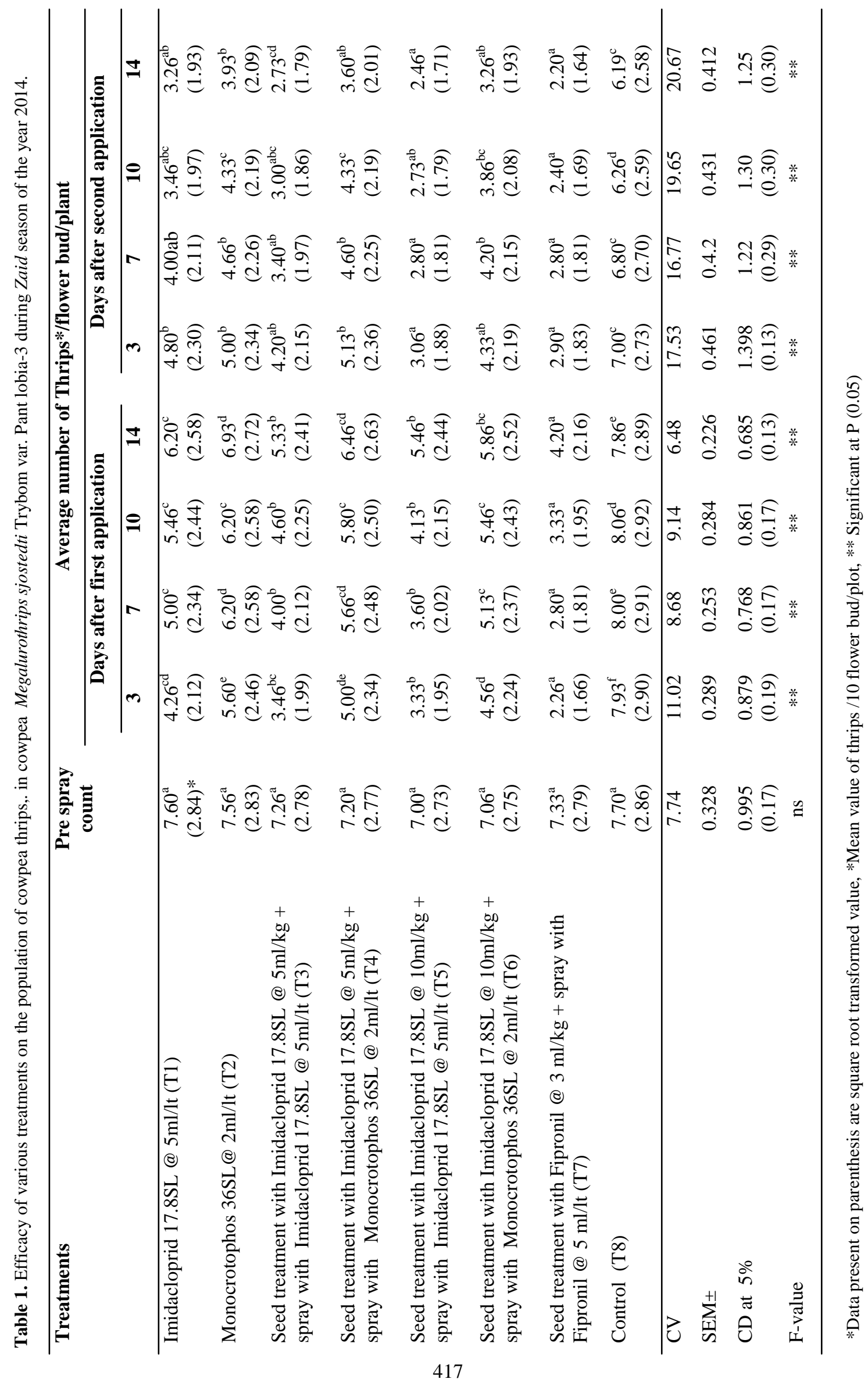




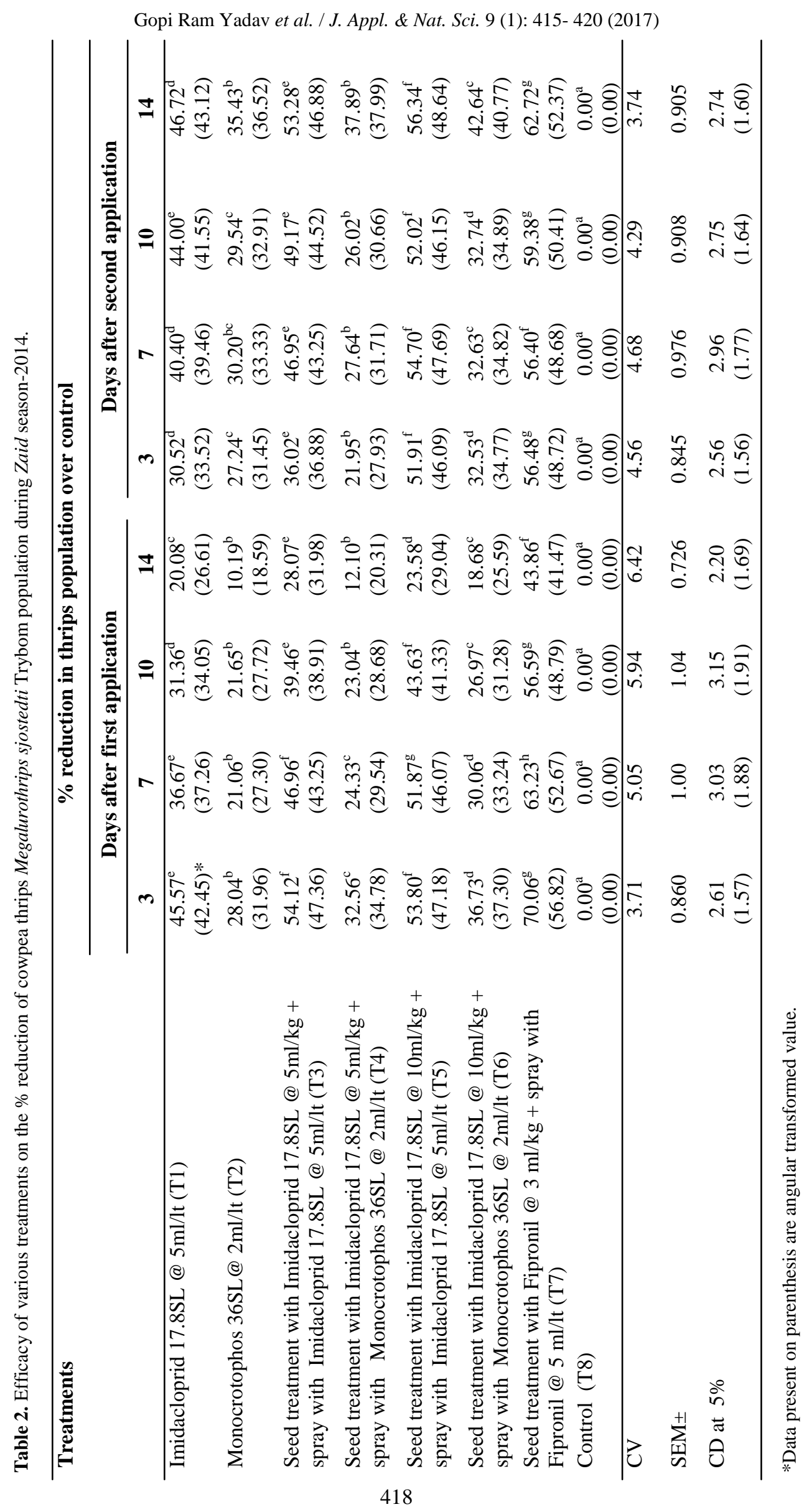


$\mathrm{ml} / \mathrm{kg}+$ spray with fipronil @ $5 \mathrm{ml} / \mathrm{lt}$ (T7) $(63.23 \%)$ followed by the treatment seed treatment with imidacloprid 17.8SL @ $10 \mathrm{ml} / \mathrm{kg}+$ spray with imidacloprid 17.8SL @ 5ml/lt (T5) (51.87\%) with thrips population 3.60 thrips/flower bud/plant. While, in the seed treatment with imidacloprid 17.8SL @ 5ml/ $\mathrm{kg}+$ spray with imidacloprid 17.8SL@ @ml/lt (T3) and imidacloprid at 17.8SL @ 5ml/lt T1, the number of thrips was 4.00 and 5.00 thrips/flower bud/plant with $46.96 \%$ and $36.67 \%$ reduction, respectively. Although, the lowest reduction was recorded in monocrotophos 36SL @ 2ml/lt (T2) with $21.06 \%$ (6.20 thrips/flower bud/plant). The $\%$ reduction in thrips population was recorded significantly higher $(\mathrm{P}<0.05)$ in treatments $\mathrm{T} 7$ and $\mathrm{T} 5$ over other treatments.

After 10 days of $1^{\text {st }}$ application, highest reduction in thrips population was observed in the treatments $\mathrm{T} 7$ with $56.59 \%$ (3.33 thrips/flower bud/plant). followed by the treatment $\mathrm{T} 5$ with $43.63 \%$ (4.13 thrips/flower bud/plant). However, the treatments $\mathrm{T} 4$ and $\mathrm{T} 2$ recorded $23.04 \%$ and $21.65 \%$ reduction in thrips population with 5.80 and 6.20 thrips/flower bud/plant, respectively and found statistically at par with each other. The \% reduction in the population was recorded significantly higher $(\mathrm{P}<0.05)$ in treatments $\mathrm{T} 7$ over other treatments.

The observations recorded after 14 days, showed that the treatment $\mathrm{T} 7$ was found to be most effective with highest reduction in thrips population (43.86\%) and had lowest number 4.20 thrips/flower bud/plant than the treatment T3 with $28.07 \%$ and 5.33 thrips/flower bud/plant. However, there was no significant difference between treatment T4 and T2 with $12.10 \%$ and $10.19 \%$ reduction, respectively. The number of thrips was gradually increased in untreated check with highest population 8.33 thrips/flower bud/plant.

Following $2^{\text {nd }}$ application after 3 days, the lowest population $(2.90$ thrips/flower bud/plant $)$ with significantly highest reduction $(56.48 \%)$ was obtained in the treatment $\mathrm{T} 7$ followed by treatment $\mathrm{T} 5$ (3.06 thrips/flower bud/plant) with $51.91 \%$ reduction. Whereas, the lowest \% reduction $(21.95 \%)$ in thrips population was recorded in the treatment T4 with 5.13 thrips/flower bud/plant. The $\%$ reduction in population was statistically at par in the treatment T6 and T1 with 32.53 and $30.52 \%$, respectively.

At 7 days, it was observed that significantly highest \% reduction in thrips population was obtained in the treatment $\mathrm{T} 7$ and $\mathrm{T} 5$ with 56.40 and $54.70 \%$ having lowest population of 2.80 thrips/flower bud/plant and found statistically at par with each other. However, significantly lowest reduction in the thrips population was obtained in treatment T4 with $27.64 \%$ and 4.60 thrips/flower bud/plant. Although highest population was recorded in untreated check with 6.80 thrips/ flower bud/plant which was significantly higher $(\mathrm{P}<0.05)$ than other treatments.
Similarly at 10 days, treatment $\mathrm{T} 7$ was recorded highest $\%$ reduction in thrips population with $59.38 \%$ and lowest number of 2.40 thrips/flower bud/plant followed by T5 with $52.02 \%$ and 2.73 thrips/flower bud/plant. However, significantly highest thrips population was obtained in treatment untreated, T4 and T2 with $6.26,4.33$ and 4.33 thrips/flower bud/plant, respectively. There was no significant difference recorded in the number of thrips among the treatments T3 (3.00 thrips/flower bud/plant) and T1 (3.46 thrips/ flower bud/plant). The $\%$ reduction in the thrips population was significantly higher $(\mathrm{P}<0.05)$ in treatments $\mathrm{T} 7$ over rest of all treatments. Thrips . is an important pest of the reproductive structures (flowers) of cowpea, with early feeding leading to flower bud and flower shedding and consequently poor pod setting (Singh and Taylor, 1978; Tamo et al., 1993).In according to Pachundkar et al., (2013) Fipronil 5 SC (0.005\%), acephate $75 \mathrm{SP}(0.075 \%)$ and carbosulfan $25 \mathrm{EC}$ $(0.025 \%)$ effectively managed thrips on cluster bean . Mahalaxami et al. (2015) reported that pinosad 45 SC and fipronil 5 SC which were proved very effective against thrips in different crops were also included to assess their efficacy against whiteflieIn accordance with the present findings, Ahmad et al. (2002) also observed that imidacloprid 25 WP @ 200 gm/acre, proved to be the best against black thrips, Caliothrips indicus after first application with mean population of 2.33 black thrips/ leaf. After second spray, imidacloprid showed the same results with 3.50 black thrips/leaf. The overall of two sprays revealed imidacloprid with 2.75 black thrips/leaf as the best treatment. The above results are also similar with Patel et al. (2012) who reported that the seed treatment of imidacloprid $70 \mathrm{WS}$ @ 5g/kg seeds and fipronil 5\%SC @ $4 \mathrm{ml} / \mathrm{kg}$ seeds found superior in reducing the population of thrips and leafhopper. Significantly higher grain yield was harvested from imidacloprid 70 WS @ 5g/kg seeds and fipronil 5\% SC @ $4 \mathrm{ml} / \mathrm{kg}$ seeds.However, the above findings is in partial agreement with the findings of Nadeem et al. (2012) who reported that the lowest number of thrips population was found in acetamiprid treatment (1.64 and 2.33 per flower) followed by imidacloprid with 3.00 thrips per flower and thiamethoxam with 3.68 thrips per flower as against 4.57 thrips per flower in control treatment. imidacloprid against $M$. distalis noticed in present study is in conformity with the report of Dalwadi (2005) who showed superior performance of this insecticide against thrips infesting Indian bean. Similarly, better performance of clothianidin and acetamiprid against thrips infesting Indian bean tend to support the finding of Patil et al. (2007) who proved effectiveness of these insecticides against thrips infesting cotton The application of insecticide sprays immediately enhanced the mortality of the pests, whereas, the effect of seed-treatment and detergent did 
not show distinctive effect on the pests population.

\section{Conclusion}

The higher effectiveness was observed with the application seed treatment with fipronil @ $3 \mathrm{ml} / \mathrm{kg}+$ spray with fipronil @ $5 \mathrm{ml} / \mathrm{lt}$ with highest reduction (70.06 \%) in the thrips, Megalurothrips sjostedti Trybom population of cowpea followed by Seed treatment with imidacloprid $17.8 \mathrm{SL} @ 5 \mathrm{ml} / \mathrm{kg}+$ spray with imidacloprid 17.8SL @ 5ml/lt with 54.12\% reduction in thrips population. However, least effective treatment was seed treatment with imidacloprid 17.8SL @ 10ml/ $\mathrm{kg}+$ spray with monocrotophos 36SL @ 2ml/lt with lowest reduction $(16.02 \%)$ in thrips, Megalurothrips sjostedti Trybom population of cowpea crop. The novel mode of action makes Fipronil and Imidacloprid a valuable option for integrated management programs in addition to safety to key beneficial arthropods and environment.

\section{REFERENCES}

Ahmad, T., Afzal, M. and Bashir, M.H. (2002). Relative toxicity of different insecticides against whitefly, Bemisia tabaci and black thrips, Caliothrips indicus on mung bean, Vigna radiate. Pak. J. Agri. Sci., 39(3)

Akibode, S. and Maredia, M. (2011). Global and Regional Trends in Production, Trade and Consumption of Food Legume Crops.

Agyen-Sampong, M. (1978). Pests of cowpea and their control in Ghana. See Ref. 175: 85-92

Akingbohungbe, A.E. (1982). Seasonal variation in cowpea crop performance at lIe-Ife Nigeria, and the relationship to insect damage. Insect Sci. Appl., 3: 287-96

Andrewartha, H.G. (1971). Introduction to the Study of Animal Populations. Chicago: Univ. Chicago Press, pp 262.

Dalwadi, M. M., 2005, Population dynamics of insect pest complex of Indian bean and their management. M. Sc. (Agri.) Thesis submitted to Anand Agric. Univ, Anand.
Ezueh, M.I. (1981). Nature and significance of pre-flowering damage by thrips to cowpea. Entomologia experimentalis et Applicata. 29(3): 305-320

Kady, H.E. and Devine, G.J. 2003. Insecticide resistance in Egyptian populations of cotton whitefly. Pest Management Science, 59: 865-871

Morse, J.G. and Hoddle, M.S. (2006). Invasion biology of thrips. Annu Rev Entomol., 51: 67-89

Mahalaxami, M.S, Sreekanth, M., Adinarayana, M and Rao, K.Y.(2015). Efficacy of some novel insecticide molecules against incidence of whiteflies (Bemisia tabaci Genn.) and occurrence of Yellow Mosaic Virus (YMV) disease in urdbean. Int. J. Pure App. Biosci., 3 (5):101106

Nadeem, M. Iqbal, J., Saddique, M. Fiaz, M.M. and Hassan, M.W. (2012). Directorate of Pest Warning \& Quality Control of pesticides, Arid Zone Research Institute Bhakkar, Pakistan

Patel, P.S. Patel, I.S. Panickar, B. and Ravindrababu, Y. ( 2012) . Management of Sucking Pests of Cowpea Through Seed Treatment. Trends in Bio. 5(2): 138-139

Patil, S. B., Udikeri, S. S., Naik, L. K., Rachappa, V., Nimbal, F. and Guruprasad, G . S., 2007. A promising new molecule for the management of cotton sap feeding insects. Karnataka J. Agric. Sci., 20(1): 47-50

Palumbo, J.C.; Horowitz, A.R. and Prabhaker, N. 2001. Insecticidal control and resistance management for $\mathrm{Be}$ misia tabaci. Crop Protection, 20: 739-765

Pachundkar, N. N, Borad, P. K., and Patil, P. A.(2013) Evaluation of Various Synthetic Insecticides against Sucking Insect Pests of Cluster Bean. International Journal of Scientific and Research .,3 (8)

Singh, S.R. Allen, D.J. (1980). Pests, diseases, and protection in cowpeas. pp 419-443

Singh, S.R. Taylor, T.A. (1978). Pests of grain legumes and their control. Pests of grain legumes: Ecology and control. London/New York, Academic Press. 99-111

Tamo, M. Baumgartner, J. Delucchi, V. Herren, H.R. (1993). Assessment of key factors responsible for the pest status of the bean flower thrips Megalurothrips sjostedti(Thysanoptera: Thripidae) in West Africa. Bulletin of Entomological Research. 83(2): 251-258 